\title{
Effect of zinc supplementation on renal and sexual function of men with diabetic nephropathy and impotence, a randomized double-blind cross over clinical trial
}

\section{Faranak Sharifi}

Zanjan University of Medical Sciences

Zahra Shajari ( $\sim$ adz.shajari@gmail.com )

Zanjan University of Medical Sciences https://orcid.org/0000-0003-2162-2063

\section{A.Amir Feizy}

Zanjan University of Medical Sciences

\section{Research}

Keywords: Zinc, Diabetic Nephropathy, Diabetes Type 2, Erectal dysfunction, Impotence

Posted Date: May 17th, 2021

DOl: https://doi.org/10.21203/rs.3.rs-502882/v1

License: (c) (1) This work is licensed under a Creative Commons Attribution 4.0 International License.

Read Full License 


\section{Abstract}

Background: Free radical generation and oxidative stress has been hypothesized to be underlying pathogenesis of diabetic complications like nephropathy and erectal dysfunction. Zinc can reduce lipid per-oxidation and improves endothelial functions. The aim of this study was to evaluate the effects of Zinc on renal and sexual function of men with Type 2 diabetes.

\section{Methods:}

This study has been supported financially by Zanjan University of Medical Sciences and registered in Iranian registry of clinical trials (www.irct.ir) with this code: IRCT138806091179N3.

Fifty adult type 2 diabetic men with diabetic nephropathy and erectal dysfunction were enrolled in doubleblind, randomized trial. Twenty-five patients received $30 \mathrm{mg}$ Zinc-sulfate per day and the remaining subjects received placebo for three months. Baseline and end-study body mass index (BMI), blood pressure (BP), fasting plasma glucose (FPG), HbA1C, lipid profiles, serum creatinine ( $\mathrm{Cr}$ ), testosterone and zinc concentrations were measured. Albumin/creatinin ratio (ACR) and glumerular filtration rate (GFR) were calculated for all the participants. Sexual dysfunction was determined with International Index for Erectile Dysfunction questionnaire (IIEF-5).

\section{Results:}

Slight non-significant reduction versus a minimal non-significant increase in mean of ACR was seen with Zinc supplementation and placebo respectively $(-3.7 \pm 17.1 \mu \mathrm{g} / \mathrm{mg}$ vs. $2.8 \pm 21.4 \mu \mathrm{g} / \mathrm{mg} ; \mathrm{P}=0.130$. Additionally Zinc supplementation had no effect on GFR and also erectile dysfunction of diabetic patients. However, significant improvement in FPG, $\mathrm{HbA1c}$, total cholesterol and HDL-cholesterol concentration were seen with zinc supplementation ( $\mathrm{p}: 0.03)$.

Conclusion: The results suggest that albuminuria, GFR and erectile function of men with type 2 DM cannot be affected by Zinc supplementation in dose of $30 \mathrm{mg} /$ day. Further studies in a larger population may be warranted.

\section{Introduction}

Diabetic nephropathy is one of the major causes of morbidity and mortality in patients with diabetes mellitus (DM) $(1,2)$. The specific pathological changes in the kidney, the clinical course, and the overall risk to develop nephropathy are quite similar in both types of diabetes (3). Conclusive evidence exists that strict control of hyperglycemia lowers the risk of nephropathy and other diabetic complications of diabetes mellitus $(4,5)$. The decline in renal function over time has been shown to relate with the initial GFR, initial urinary albumin excretion rate (UAE), hyperglycemia, hypertension, age and sex (6, 7).Endothelial dysfunction and changes in vascular permeability are considered as the first steps of 
diabetic nephropathy. Additionally renal microvascular changes may be accompanied by other microvascular complications of DM like retinopathy, neuropathy and sexual dysfunction.

On the other hand, it has been reported that $49 \%$ of men with type 2 diabetes after age 65 have erectile dysfunction (13). This is even more common in those with a longer duration of diabetes, poor glycemic control, higher body mass index (BMI), smokers and those with other diabetes micro or macrovascular complications like nephropathy.

Erectile dysfunction in diabetic men may be result of neuropathy, endothelial dysfunction and smoothmuscle changes which can be all together the harmful effects of free radicals and lack of antioxidants (14).

Free radical generation and oxidative stress due to increased production of plasma free radical and decreased antioxidant defense has been hypothesized to be underlying pathogenesis of diabetic complications (8-10). Free radicals are considered to play key roles in hyperglycemia (11) hyperinsulinemia and/or insulin resistance (12).

Thereupon, it is assumed that antioxidant supplement therapies such as vitamin E, vitamin C, Chromium and zinc, reduce lipid per-oxidation and improve insulin-glucose imbalance and endothelial function. To address the current deficient knowledge of zinc supplementation effect on albuminuria and erectile dysfunction of men with diabetes mellitus this study was designed.

\section{Materials And Methods}

\section{Study population:}

A double- blind, cross over clinical trial was designed to evaluate the efficacy of zinc supplements on renal function, albuminuria and erectile dysfunction of men with type $2 \mathrm{DM}$. The subjects were randomly selected from patients who referred to diabetes clinic of vali-e-Asr hospital, a referral academic hospital in Zanjan.

Fifty men with type 2 DM whose albuminuria has been detected newly by two times measurement of 24$\mathrm{h}$ urinary albumin excretion was enrolled in this study. Albuminuria more than $30 \mathrm{mg} / 24 \mathrm{~h}$ in double checking and reconfirmation with $\mathrm{ACR}>=30 \mu \mathrm{g} / \mathrm{mg}$ in the absence of other causes of albuminuria defined as diabetic nephropathy in this study. Coexistence of erectile dysfunction, using international index of erectile function -5 (IIEF-5), made the patients eligible for this study.

All the subjects with history of any forms of supplement therapy in the previous 6 months and those who suffered from active urinary tract infection based on urinary analysis test were excluded. We also excluded all the participants with glomerular filtration rate (GFR) less than $30 \mathrm{~mL} / \mathrm{min}$, other causes of albuminuria and hypogonadism, acute or chronic inflammation or active liver disease. Patients who are not satisfied to participate or not to pursue a regular observe or medication allergies happened for them, were excluded from the study. 
The details of the study were explained to the participants and informed-consent was obtained. A local ethical committee approved the study. This clinical trial was approved in the Iran registry of clinical trial (IRCT code: IRCT138806091179N3 ).

\section{Measurements:}

Before and at the end of first and second phase of the study, the measurements were done. We recorded demographic, anthropometric and clinical information of patients. Blood pressure was measured by a mercury barometer after 10 min resting in sitting position; weight was measured in minimum dressing by Seca scale with the accuracy of $0.1 \mathrm{~kg}$. Height of the subjects was measured by standard methods and body mass index (BMI) was calculated.

All the subjects had laboratory measurements including FPG, HbA1C, lipid profile (total cholesterol,HDL-C, LDL-C and triglyceride), serum creatinine ( $\mathrm{Cr}$ ), serum zinc and testosterone level and also albumin to creatinine ratio(ACR) at the first and after the end of first and second phase of the study. Two different urine samples were obtained to measure ACR and mean of them was reported as final ACR result at the two stages of the study.

All the laboratory examinations were done in one laboratory center and the assays were unchanged during the study period. Creatinine was measure by Jaff method and glomerular filtration rate was calculated using Cockcroft_gault formula; GFR $=([140$-age $($ years $)] \times$ Weight $(\mathrm{kg}) / 72 \times \mathrm{Pcr}) \times 0.085$.

HemoglobinA1c levels were measured using lone exchange method by $\mathrm{DS}_{5}$ device set. Lipid profiles were determined by the colorimetric enzymatic method and by auto analyzer; Cubas Mira. Urine Albumin was checked by nephelometry method and by using Binding Site kits (UK). The inter-assay CV of the kit was $4.1 \%$ for higher levels of albumin and 3.1\% for lower levels of it. Intra-assay CV for the kit was $2.6 \%$ for upper levels and $2.2 \%$ for lower levels of albumin.

Detection sensitivity of zinc kit was also $3 \mu \mathrm{mol} / \mathrm{L}$ and normal zinc ranges from 4.1 up to $4.16 \mu \mathrm{mol} / \mathrm{L}$.

International Index of Erectile Function -5 (IIEF-5) was used to detect erectile function of the subjects. IIEF5 is a sexual function questionnaire contains 15 questions with 5 or 6 choices. Score between 0-5 awards to each of the items. Impairment of erectile function is assessing by 6 questions of 15 with a maximum score of 30 and score of 20 or less than that is considered to erectile dysfunction.

\section{Study protocol:}

A randomized two- phase, double blind study was assigned. At first, participants were categorized randomly and equally into two zinc-experimental and placebo-control groups and received zinc or placebo for a three- month period. Then they were undergone 1 month (4 weeks) of wash out period. Finally, reverse placebo or zinc intervention was conducted as second phase for additional three months. Any documented side effects of the medications were recorded. 
Twenty-five men in experimental group received one capsule of zinc - sulfate per day containing $30 \mathrm{mg}$ elemental zinc (made by Iran_Al-havi Company) for 3months. The other twenty-five subjects in control group received placebo in similar designed to zinc capsules. The medications were distributed and checked by a third person. Patients advised to continue their previous medications with the same dose throughout the study. To ensure the drug taking, patients were asked to have two controlling visits during the study and bring their medication cartridge. In every visit, subjects were reassessed for their blood pressure, weight, BMI and the medication side effects.

\section{Statistical analysis:}

All data are showed as mean $( \pm S D)$. The comparison between the groups of patients was performed using Student $t$ tests for quantitative independent variables and Chi square test for qualitative one. Paired T test was used to evaluate the changes in variables in one group. For nonparametric data, mann_Witney Test and Wilcoxon Signed Ranks test were applied. Log transformation was done for ACR to change it to a normal distributed variable. For emission of confounding variables effect, we used multivariate linear regression analysis.

For determination of normal distribution of variables, Komogorov_Sminrnov test was applied. Collected data were analyzed by SPSS version 16 . Significance was defined as $P<0.05$.

\section{Results}

A total of 50 men enrolled in the study. Eight patients (4 patients in each group) were excluded from the study including 3 people with incorrect use of prescribed medication, 2 patients with refusing follow-up and 2 subjects with no consent to continue their treatment. one patient was withdrawn from the experimental group because of GI complications . Finally, forty two individuals completed the study (21 subjects in experimental-zinc group and 21 in control- placebo group). There were no significant differences between the two groups in term of their clinical characteristics. Basal characteristics of the two groups are illustrated in Table $1 a, b$.

All the participants had normal serum concentrations of Zinc that remained in normal range after receiving Zinc supplements during the study. No significant difference was found for serum Zinc concentrations between the groups at baseline and after the intervention. (figure1). No zinc toxicity was reported after zinc supplementation.

\section{Renal Parameter:}

No significant changes were seen in the GFR of the participants with Zinc supplementation. According to Table 2, although GFR showed slight decrease $(-0.02 \mathrm{ml} / \mathrm{min})$ and mild elevation $(+0.88 \mathrm{ml} / \mathrm{min})$ in the experimental and placebo groups respectively, these changes seen were not significant (P: 0.569, P: $0.418)$. 
ACR was approximately similar in both groups before the intervention. At the end of the intervention, a non significant reduction in ACR was seen in the experimental group. Mean of changes of ACR was not significantly different between experimental and control groups $(-3.7 \mu \mathrm{g} / \mathrm{mg}$ decrement $\mathrm{Vs} 2.8 \mu \mathrm{g} / \mathrm{mg}$ increment respectively, p: 0.13) (Table 2).

\section{Metabolic parameters}

Mean duration of DM confirmation for both zinc and placebo groups was 10.5 and 10.9 years old respectively. Fasting blood glucose (FPG) did not differ between the two groups before intervention. After complement of 3 months of the intervention, FPG decreased $21.2 \mathrm{mg} / \mathrm{dl}(P<0.0001)$ with zinc supplementation. This considerable decrease was approved with significant reduction of $\mathrm{HbA} 1 \mathrm{C}$ level $(0.3 \% ; p<0.0001)$ (table 3).

Lipid profile was not different between the two groups at baseline. But, after 3 months of zinc supplementation, total cholesterol and LDL-c concentrations reduced significantly $(-4.1 \mathrm{mg} / \mathrm{dL}$ and $-5.1 \mathrm{mg} / \mathrm{dL}$; P: 0.031 and $\mathrm{P}: 0.01$ respectively). Also HDL level elevated remarkably after receiving three months of zinc supplement (P: 0.002) (table 3).

Other metabolic parameters including BMI, SBP and DBP did not show any significant changes with the intervention.

\section{Sexual parameters:}

No significant changes were seen for serum testosterone concentrations with Zinc supplements (table 7).

Assessments of erectile dysfunction by IIEF- 5 before the intervention demonstrated score 13.9 for zincexperimental group and score 13.4 for placebo-control group. However, statistically significant improvements of erectile dysfunction were not presented in the groups after the intervention (table 1).

\section{Discussion}

Our clinical research investigated effect of zinc supplementation on albuminuria and sexual (erectile) dysfunction of men with DM. We didn't find any significant changes of GFR, ACR and erectile function of the subjects after seven months of follow up and with a cross over design for the Zinc supplementation and placebo. Although total ACR and GFR were decreased slightly during zinc supplementation in comparison to pre-treatment, it was not remarkable.

it is assumed that diabetic complications including nephrophathy, retinopathy or erectile dysfunction are induced by production of plasma free radicals; hyperglycemia hyperinsulinemia and/or insulin resistance(8-12).On the other hand impaired metabolism of several trace elements, such as copper , zinc , manganese, and magnesium have been reported to be associated with impaired insulin release, insulin resistance, and glucose intolerance in experimental animals and humans(15-22). 
Several mechanisms are hypothesized for anti-oxidative effect of zinc in diabetes. Zinc maintains integrity of Cu-Zn -SOD structure $(27,28)$. This complex provides protection against immune-mediated free-radical attack in the islet cells of pancreas (29).Protection of sulfhydryl groups against oxidation, inhibition of the free radical production in the Haber Weiss cycle by competing with transition metals (30), preventing proteins from oxidation are supposed to be the other mechanisms(31). Zinc also plays a role as a cofactor for caspases(32)and enzymes of nucleic acid catabolism. Also, Zinc reserve depletion results in cellular death by apoptosis (33).

Our results did not reveal zinc insufficiency in the studied patients. Without causing zinc toxicity, we evaluated the anti oxidant effect of zinc supplements on complication of diabetes. GFR and albumin/creatinine ratio (ACR) were not reduced significantly in our study with $30 \mathrm{mg} / \mathrm{d}$ of Zinc supplementation. This findings are not consistent with results of other published studies, in which the urinary albumin excretion ratio was decreased in diabetic patients who had received $30 \mathrm{mg}$ zinc and magnesium (24) or zinc and melatonin for 3 months (25) or zinc supplement alone for 3 months (26).However, in consistent with our results; a systematic review did not confirm a role of zinc supplementation in the prevention of type 2 diabetes(34). All of the participants in our study were Zinc sufficient. That might be deduced that zinc supplement for diabetic patients with normal zinc levels is not generally beneficial.

Diabetes is one of the systemic disorders most frequently associated with erectile dysfunction, due to vascular and/or neurological damage (35). Patients with diabetes and poor glycaemic control as well as metabolic syndrome also have higher rates of hypogonadism, retrograde ejaculation and reduced libido (36).

Zinc affects different aspects of mammalian reproduction. Testicular disruption, impaired spermatogenesis and subsequent poor semen parameters are found in males with zinc deficiency (37). Zinc therapy improved sexual competence of male rats' model in Dissanayake and his colleagues' study. They found that this effect is dose dependent and an increase in testosterone level was reported after zinc therapy and considered as a beneficial mechanism of the intervention. However, elevated levels of prolactin was detected in this model could be considered as a responsible factor for the reduced libido (38).

All the participants in our study have suffered from erectile dysfunction according to score obtained by International Index of Erectile Function (IIEF-5) questionnaire. Nevertheless, in our study, zinc administration had no significant effect on any aspects of sexual function. Plasma basal testosterone level was also unaltered by zinc administration. These results are in the line with few previous studies in this field (39-40).Absence of Zinc deficiency in the study population or low-dose zinc supplementation may be causes of the mentioned results. We followed our patients for three months in each phases of the study that may be not enough to see clinical improvements in impotence.

Our investigation showed that FPG and $\mathrm{HbA} 1 \mathrm{c}$ have been modulated significantly after zinc supplementation. Contrary, there are some reports of no significant changes of FPG with zinc intake (24, 
25 , 35). However; reduction in $\mathrm{HbA} 1 \mathrm{c}$ was reported with zinc administration in one another study (26). In that study Zinc supplementation decreased $\mathrm{HbA} 1 \mathrm{c}$ with no effect on fasting plasma glucose and they concluded that this may be due to the effect of zinc on post prandial plasma glucose concentration.

We found a significant fall in total cholesterol, LDL-C, and triglyceride concentration and also an elevation in HDL-c level after three months of zinc supplement therapy. Similar to our study, Gunasekara study showed that treatment with multivitamin-mineral with or without zinc can reduce serum TG and LDL-C levels and increase HDL-c concentrations (36). These observations are consistent with those reported by whereby a group of poorly controlled diabetes patients were supplemented with zinc and melatonin for a period of 3 months $(37,38)$. However, in all of these studies co-administration of zinc with other materials like melatonin or vitamins make some confusion about the main cause of changes in lipid profile reported by them. Our results with administration of Zinc alone could be a confirmation of the effect of zinc on these metabolic components. . Nevertheless, there are some studies and review reported zinc supplementation on lipid profile may delay the progression to and may beneficially have an influence on lipid profile in the patients with type 2 diabetes mellitus especially young adults. (39-40)

\section{Conclusion}

In conclusion although zinc supplementation could make some improvement in blood glucose and lipid concentrations no improvement in GFR, ACR and erectile function of the participants could be expected with $30 \mathrm{mg} / \mathrm{d}$ of elemental zinc for at least three months of treatment in diabetic patients without zinc deficiency.

\section{Limitation}

It was better if participants with zinc deficiency were included in the study. Zinc supplement therapy is preferred in those with zinc insufficiency and could compare with normal ones. Also, it was better that if our intervention was designed with longer duration of follow up to achieve a more complete assessment.

\section{Declarations}

\section{Ethic approval and consent to participate:}

This study was registered in Iranian registry of clinical trials (www.irct.ir) with this code:

\section{IRCT138806091179N3 an}

\section{Ethics committee reference number: $1617 / 3-3 / 19$}

Consent for publication/: All authors confirmed manuscript and are informed about journal submission. our manuscript does not contain no other data from any individual person, please state "Not applicable" in this section. 


\section{Authors' contributions:}

1-Faranak Shariff: design clinical trial, interpreted the patient data, and revised manuscript

2-Zahra Shajari: design clinical trial, Collection Data,writing the manuscript, and corresponding Author

3- A.Amir. Feizy: design clinical trial, laboratory testing and analaysis

Availability of data and materials: The datasets used and/or analysed during the current study are available from the corresponding author on reasonable. With the submission of this manuscript, I would like to undertake the responsibility that the above mentioned manuscript has not been published totally or partly, accepted for publication or under editorial review for publication elsewhere.

Competing interests: Not applicable

Funding: This project was a residency thesis and has been supported financially by Zanjan University of Medical Sciences and

The authors declare that they have no conflict of interest.

Acknowledgements: We also have no copyright holder to republish previously published material, from the patient or legal guardian for publication of recognizable photographs, and/or from no specific person named in the Acknowledgment.

\section{References}

1. Salgueiro MJ, Krebs N, Zubillaga MB, et al. Zinc and diabetes mellitus: is there a need of zinc supplementation in diabetes mellitus patients?. Biol Trace Elem Re. 2001; 81(3): 215-28.

2. Parham M, Amini M, Aminorroaya A, Heidarian E. Effect of zinc supplementation on microalbuminuria in patients with type 2 diabetes: a double blind, randomized, placebo-controlled, cross-over trial. Rev Diabet Stud. 2008; 5(2): 102-9.

3. Newman DJ, Mattock MB, Dawnay AB. Systematic review on urine albumin testing for early detection of diabetic complications. Health Technol Assess. 2005; 9(30): 155-63.

4. McCulloch DK, Bakris GL. Microalbuminuria in type 2 diabetes mellitus. Up To Date, Online 2020/03, Available from URL: www.UpToDate.Com.

5. Mogensen $C E$, Vestbo E, Poulsen PL, et al. Microalbuminuria and potential confounders. A review and some observations on variability of urinary albumin excretion. Diabetes Care. 1995; 18(4): 57281.

6. Costacou T, Ellis D, Fried L, Orchard TJ. Sequence of progression of albuminuria and decreased GFR in persons with type 1 diabetes: a cohort study. Am J Kidney Dis. 2007; 50(5): 721-32.

7. Amini $M$, Safaei $H$, Aminorroaya $A$. The incidence of microalbuminuria and its associated risk factors in type 2 diabetic patients in Isfahan, Iran. Rev Diabet Stud. 2007; 4(4): 242-8. 
8. Yokoyama H, Kawai K, Kobayashi M; Japan Diabetes Clinical Data Management Study Group. Microalbuminuria is common in Japanese type 2 diabetic patients: a nationwide survey from the Japan Diabetes Clinical Data Management Study Group (JDDM 10). Diabetes Care. 2007; 30(4): 989-92.

9. Faure P, Roussel A, Coudray C, Richard MJ, Halimi S, Favier A. Zinc and insulin sensitivity. Biol Trace Elem Res. 1992; 32: 305-10.

10. Arquilla ER, Packer S, Tarmas W, Miyamoto S. The effect of zinc on insulin metabolism. 1978; 103(4): 1440-9.

11. Niedowicz DM, Daleke DL. The role of oxidative stress in diabetic complications. Cell Biochem Biophys. 2005; 43(2): 289-330.

12. Kelly FJ. Use of antioxidants in the prevention and treatment of disease. J Int Fed Clin Chem. 1998; 10(1): 21-3.

13. Anderson RA, Roussel AM, Zouari N, Mahjoub S, Matheau JM, Kerkeni A. Potential antioxidant effects of zinc and chromium supplementation in people with type 2 diabetes mellitus. J Am Coll Nutr. 2001; (3): 212-8.

14. Kinlaw WB, Levine AS, Morley JE, Silvis SE, McClain CJ. Abnormal zinc metabolism in type II diabetes mellitus. Am J Med. 1983; 75(2): 273-7.

15. Andreoli TE, Carpenter CCJ, Griggs RC, Benjamin IJ. Andreoli and Carpenter's Cecil Essentials of Medicine. 26th ed., Philadelphia: WB Saunders Company, 2019, Chap: 68.

16. Hagay ZJ, Weiss Y, Zusman I. Prevention of diabetes-associated embryopathy by overexpression of the free radical scavenger copper zinc superoxide dismutase in transgenic mouse embryos. Am $\mathrm{J}$ Obstet Gynecol. 1995; 173(4): 1036-41.

17. Faure P, Benhamou PY, Perard A, Halimi S, Roussel AM. Lipid peroxidation in insulin-dependent diabetic patients with early retina degenerative lesions: effects of an oral zinc supplementation. Eur $\mathrm{J}$ Clin Nutr. 1995; 49(4): 282-8.

18. Farvid MS, Jalali M, Siassi F, Hosseini M. Comparison of the effects of vitamins and/or mineral supplementation on glomerular and tubular dysfunction in type 2 diabetes. Diabetes Care. 2005; 28(10): 2458-64.

19. Kadhim HM, Ismail SH, Hussein KI, et al. Effects of melatonin and zinc on lipid profile and renal function in type 2 diabetic patients poorly controlled with metformin. J Pineal Res 2006; 41(2): 18993.

20. Goldiner WH, Hamilton BP, Hyman PD, Russell RM. Effect of the administration of zinc sulfate on hypogonadism and impotence in patients with chronic stable hepatic cirrhosis. J Am Coll Nutr.1983; 2(2): 157-62.

21. Brook AC, Johnston DG, Ward MK, Watson MJ, Cook DB, Kerr DN. Absence of a therapeutic effect of zinc in the sexual dysfunction of haemodialysed patients. Lancet.1980; 2(1): 618-20.

22. Jalali GR, Roozbeh J, Mohammadzadeh A, et al. Impact of oral zinc therapy on the level of sex hormones in male patients on hemodialysis. Ren Fail. 2010; 32(4): 417-9. 
23. Dissanayake D, Wijesinghe PS, Ratnasooriya WD, Wimalasena S. Effects of zinc supplementation on sexual behavior of male rats. J Hum Reprod Sci. 2009; 2(2): 57-61.

24. Roussel AM, Kerkeni A, Zouari N, Mahjoub S, Matheau JM, Anderson RA. Antioxidant effects of zinc supplementation in Tunisians with type 2 diabetes mellitus. J Am Coll Nutr. 2003; 22(4): 316-21.

25. Al-Maroof RA, Al-Sharbatti SS. Serum zinc levels in diabetic patients and effect of zinc supplementation on glycemic control of type 2 diabetics. Saudi Med J 2006; 27: 344-50.

26. Raz I, Karsai D, Katz M. The influence of zinc supplementation on glucose homeostasis in NIDDM. Diabetes Res. 2010; 11(2): 73-9.

27. Faure P, Roussel A, Coudray C, Richard MJ, Halimi S, Favier A. Zinc and insulin sensitivity. Biol Trace Elem Res. 1992; 32: 305-10.

28. Hasslacher C, Bostedt-Kiesel A, Kempe HP, Wahl P. Effect of metabolic factors and blood pressure on kidney function in proteinuric type 2 (non-insulin-dependent) diabetic patients. Diabetologia. 1993; 36: 1051-6.

29. Ellis D, Lloyd C, Becker DJ, Forrest KY, Orchard TJ. The changing course of diabetic nephropathy: lowdensity lipoprotein cholesterol and blood pressure correlate with regression of proteinuria. Am J Kidney Dis. 1996; 27: 809-18

30. Wirta OR, Pasternack Al, Mustonen JT, Koivula TA, Harmoinen A. Urinary albumin excretion rate and its determinants after 6 years in non-insulin-dependent diabetic Nephrol Dial Transplan. 1996; 11: 449-56.

31. Roussel AM, Kerkeni A, Zouari N, Mahjoub S, Matheau JM,Anderson RA. Antioxidant Effects of Zinc Supplementation in Tunisians with Type 2 Diabetes Mellitus. Journal of the American College of Nutrition. 2003; 22( 4): 316-321.

32. Heidarian E, Amini M, Parham M, Aminorroaya A. Effect of Zinc Supplementation on Serum Homocysteine in type 2 Diabetic Patients with Microalbuminuria. The review of diabetes study. 2009; 6(1): $64-70$

33. Seet R, Lee CY, Lim E, Quek A, Huang H. Oral zinc supplementation does not improve oxidative stress or vascular function in patients with type 2 diabetes with normal zinc levels. $2011 ; 219$ : 231-9

34. Wylie K, Kenney G . Sexual dysfunction and the ageing male. 2010; 65:23

35. Fiuk J, Tadros Erectile dysfunction in renal failure and transplant patients. Transl Androl Urol 2019; 8(2): 155-163.doi: 10.21037/tau.2018.09.04

36. Sadat M, Siassi F, Jalali M, Hosseini M. Comparison of the Effects of Vitamins and/or Mineral Supplementation on Glomerular and Tubular Dysfunction in Type 2 Diabetes. Diabetes Care 2005; 28:2458-464

37. Dana M. Niedowicz and David L. Daleke. The Role of Oxidative Stress in Diabetic Complications. Cell Biochemistry and Biophysics. 2015; 43: 289-330

38. Gunasekara P, hettiarachchi M , Liyanage Ch, Lekamwasam S. effects of zinc and multimineral vitamin supplementation on glycemic and lipid control in adult diabetes. Diabetes, Metabolic 
Syndrome and Obesity: Targets and Therapy. 2011; 4: 53-60

39. Asbaghi O, Sadeghian M, Fouladvand F, Panahandeh B, Nasiri M, Khodadost M, et al. Effects of zinc supplementation on lipid profile in patients with type 2 diabetes mellitus: A systematic review and meta-analysis of randomized controlled trials. Nutrition, Metabolism and Cardiovascular 2020;30: $1260-271$

40. Karandish M, Mozaffari-khosravi H, Mohammadi SM, Azhdari M, Cheraghian B. Evaluation of the effect of curcumin and zinc co-supplementation on glycemic measurements, lipid profiles, and inflammatory and antioxidant biomarkers in overweight or obese prediabetic patients: a study protocol for a randomized double-blind placebo-controlled phase 2 clinical trial. Trials. 2020; 21:991

\section{Tables}

Table 1a: clinical and biomedical characteristics of diabetes subjects in zinc-placebo groups before and after first 3months intervention

\begin{tabular}{|l|c|c|c|c|}
\hline \multicolumn{1}{|c|}{ Variable } & \multicolumn{3}{|c|}{ First 3-month intervention } \\
\cline { 2 - 5 } & \multicolumn{3}{|c|}{ Before } & After \\
\cline { 2 - 5 } & $\begin{array}{c}\text { Zinc-group } \\
\text { N=21 }\end{array}$ & $\begin{array}{c}\text { Placebo-group } \\
\text { N=21 }\end{array}$ & $\begin{array}{c}\text { Zinc-group } \\
\text { N=21 }\end{array}$ & $\begin{array}{c}\text { Placebo-group } \\
\text { N=21 }\end{array}$ \\
\hline $\begin{array}{l}\text { BMI } \\
\left(\mathrm{kg} / \mathrm{m}^{2}\right)\end{array}$ & $26.9 \pm 2.5$ & $27.5 \pm 3.3$ & --- & -- \\
\hline $\begin{array}{l}\text { SBP } \\
(\mathrm{mmHg})\end{array}$ & $138 \pm 3.15$ & $134.1 \pm 15.3$ & $136.2 \pm 11.9$ & $135 \pm 13$ \\
\hline $\begin{array}{l}\text { DBP } \\
(\mathrm{mmHg})\end{array}$ & $85.7 \pm 3.7$ & $82 \pm 3.7$ & $85.2 \pm 4.7$ & $84.5 \pm 6.1$ \\
\hline $\begin{array}{l}\text { FBS } \\
(\mathrm{mg} / \mathrm{dL})\end{array}$ & $140.2 \pm 47$ & $162.8 \pm 56.4$ & $112 \pm 22.3$ & $131.2 \pm 31.5$ \\
\hline $\begin{array}{l}\text { HbA1C } \\
(\%)\end{array}$ & $8.9 \pm 0.8$ & $8.8 \pm 1.5$ & $7.7 \pm 0.6$ & $8.2 \pm 1$ \\
\hline $\begin{array}{l}\text { Cholesterol } \\
(\mathrm{mg} / \mathrm{dL})\end{array}$ & $172.7 \pm 34.6$ & $186.9 \pm 32.5$ & $167.7 \pm 29.8$ & $182.3 \pm 27.5$ \\
\hline \begin{tabular}{l} 
TG(mg/dL) \\
\hline
\end{tabular} & $171.9 \pm 73.1$ & $211.9 \pm 108.6$ & $172 \pm 67.3$ & $196.9 \pm 74.4$ \\
\hline $\begin{array}{l}\text { HDL } \\
(\mathrm{mg} / \mathrm{dL})\end{array}$ & $38.7 \pm 1.4$ & $39.6 \pm 1.4$ & $39.7 \pm 2.4$ & $39.8 \pm 2.2$ \\
\hline $\begin{array}{l}\text { LDL } \\
(\mathrm{mg} / \mathrm{dL})\end{array}$ & $102.2 \pm 28.8$ & $104.9 \pm 30.5$ & $95.6 \pm 26.8$ & $103.1 \pm 26.2$ \\
\hline $\begin{array}{l}\text { ACR } \\
(\mu g / m g)\end{array}$ & 170.1235 .1 & $186.1 \pm 276.9$ & $170.7 \pm 23.7$ & $186.1 \pm 257.5$ \\
\hline $\begin{array}{l}\text { GFR (mL/min) } \\
(\mu \mathrm{g} / \mathrm{dL})\end{array}$ & $39.8 \pm 8.8$ & $43.3 \pm 17.3$ & $39.5 \pm 8.8$ & $44.7 \pm 14.2$ \\
\hline $\begin{array}{l}\text { IIEF-5 Score } \\
(\mathrm{nm} / \mathrm{dL})\end{array}$ & $13.9 \pm 5.7$ & $13.4 \pm 6.4$ & $13.9 \pm 5.7$ & $103 \pm 26.5$ \\
\hline
\end{tabular}


*-p value is $<0.05$ and statistically significant. We did not find any significant difference in none of variables within 2 groups' comparison in 2 phase of intervention

\begin{tabular}{|c|c|c|c|c|c|}
\hline \multirow[t]{3}{*}{ Variable } & \multicolumn{5}{|c|}{ Second 3-month intervention } \\
\hline & \multicolumn{2}{|l|}{ Before } & \multicolumn{3}{|l|}{ After } \\
\hline & $\begin{array}{l}\text { Zinc- } \\
\text { group } \\
\mathrm{N}=21\end{array}$ & $\begin{array}{l}\text { Placebo-group } \\
\mathrm{N}=21\end{array}$ & $\begin{array}{l}\text { Zinc- } \\
\text { group } \\
\text { N=21 }\end{array}$ & $\begin{array}{l}\text { Plac } \\
\mathrm{N}=2\end{array}$ & bo-group \\
\hline $\begin{array}{l}\text { BMI } \\
\left(\mathrm{kg} / \mathrm{m}^{2}\right)\end{array}$ & $27.4 \pm 1.3$ & $27 \pm 2.6$ & & - & \\
\hline $\begin{array}{l}\text { SBP } \\
(\mathrm{mmHg})\end{array}$ & $138.1 \pm 15.3$ & $137.9 \pm 12.4$ & 134 & 10.7 & $139.1 \pm 16.6$ \\
\hline $\begin{array}{l}\text { DBP } \\
(\mathrm{mmHg})\end{array}$ & $83.8 \pm 1.7$ & $85.9 \pm 6.8$ & & \pm 6.6 & $85.8 \pm 6.6$ \\
\hline $\begin{array}{l}\text { FBS } \\
(\mathrm{mg} / \mathrm{dL})\end{array}$ & $133.5 \pm 21.3$ & $110.9 \pm 29.2$ & 118. & \pm 17.8 & $\begin{array}{c}* \\
115.6 \pm 16.8\end{array}$ \\
\hline $\begin{array}{l}\text { HbA1C } \\
(\%)\end{array}$ & $8 \pm 0.8$ & $7.6 \pm 0.5$ & & 0.5 & $\begin{array}{c}* \\
7.4 \pm 0.3\end{array}$ \\
\hline $\begin{array}{l}\text { Cholesterol } \\
\text { (mg/dL) }\end{array}$ & $174.3 \pm 28.7$ & $169.2 \pm 30.4$ & 171 & $=32.5$ & $165.9 \pm 31$ \\
\hline (mg/dL) & $185.5 \pm 59.9$ & $173.7 \pm 54.4$ & 181. & \pm 62.2 & $171.1 \pm 49.5$ \\
\hline $\begin{array}{l}\text { HDL } \\
(\mathrm{mg} / \mathrm{dL})\end{array}$ & $38.1 \pm 3.6$ & $38.5 \pm 2.3$ & & \pm 2.2 & $39.5 \pm 1.7$ \\
\hline $\begin{array}{l}\mathrm{LDL} \\
(\mathrm{mg} / \mathrm{dL})\end{array}$ & $99.1 \pm 27.7$ & $95.9 \pm 27.8$ & 95.4 & 29.6 & $92.2 \pm 27.9$ \\
\hline $\begin{array}{l}\text { ACR } \\
(\mathrm{uq} / \mathrm{mq})\end{array}$ & $185 \pm 253.2$ & $175.4 \pm 235.8$ & 177 & 246.9 & $180.9 \pm 236.1$ \\
\hline GFR (mL/min) & $44.5 \pm 13.6$ & $39.3 \pm 8.5$ & 44.7 & 13.8 & $39.6 \pm 8.9$ \\
\hline $\begin{array}{l}\mathrm{Zn} \\
(\mu g / d L)\end{array}$ & $98.9 \pm 14.9$ & $99.9 \pm 12.3$ & 104. & \pm 21.9 & $100 \pm 11.2$ \\
\hline IIEF-5 Score & $13.8 \pm 6.3$ & $13.9 \pm 5.7$ & & \pm 6.3 & $13.9 \pm 5.7$ \\
\hline $\begin{array}{l}\text { Testosterone } \\
(\mathrm{nm} / \mathrm{dL})\end{array}$ & $8.7 \pm 1.4$ & $8.2 \pm 1.5$ & & 1.1 & $8.3 \pm 1.7$ \\
\hline
\end{tabular}

Table 1b: clinical and biomedical characteristics of diabetes subjects in zinc-placebo groups before and after second 3months intervention

*-p value is $<0.05$ and statistically significant.

Table 2: mean of variation in clinical and biomedical parameters of total diabetes subjects after complete zinc supplementation therapy based on type of intervention 


\begin{tabular}{|c|c|c|c|c|}
\hline \multirow[t]{2}{*}{ Variable } & \multicolumn{2}{|c|}{ Type of intervention } & \multirow{2}{*}{ CI95\% } & \multirow{2}{*}{$P$ value } \\
\hline & $\begin{array}{c}\text { Zinc } \\
\text { (mean of variation) }\end{array}$ & $\begin{array}{c}\text { Placebo } \\
\text { (Mean of variation) }\end{array}$ & & \\
\hline $\begin{array}{l}\text { SBP } \\
(\mathrm{mmHg})\end{array}$ & $8.7 \pm-1.6$ & $11.1 . \pm 1.1$ & $-1.6 \_7.1$ & 0.49 \\
\hline $\begin{array}{l}\text { DBP } \\
\text { (mmHg) }\end{array}$ & $6.9 \pm-0.9$ & $5.5 \pm 0.7$ & $-4.4 \_1$ & 0.28 \\
\hline $\begin{array}{l}\text { FBS } \\
(\mathrm{mg} / \mathrm{dL})\end{array}$ & $32.5 \pm-2.21$ & $36.7 \pm-13.9$ & $-22.5 \_8$ & 0.34 \\
\hline $\begin{array}{l}\text { HbA1C } \\
(\%)\end{array}$ & $0.4 \pm-0.3$ & $0.5 \pm-0.4$ & $-0.1 \_0.3$ & 0.47 \\
\hline $\begin{array}{l}\text { Cholesterol } \\
\text { (mg/dL) }\end{array}$ & $12 \pm-1.4$ & $11.2 \pm-4$ & $-2.5 \_4.9$ & 0.94 \\
\hline $\begin{array}{l}\mathrm{TG} \\
(\mathrm{mg} / \mathrm{dL})\end{array}$ & $27.7 \pm-1.8$ & $27.1 \pm-8.8$ & $-4.8 \_18.9$ & 0.57 \\
\hline $\begin{array}{l}\mathrm{HDL} \\
(\mathrm{mg} / \mathrm{dL})\end{array}$ & $2.2 \pm 1.1$ & $2.2 \pm 0.5$ & $-0.4 \_1.6$ & 0.21 \\
\hline $\begin{array}{l}\mathrm{LDL} \\
(\mathrm{mg} / \mathrm{dL})\end{array}$ & $12.1 \pm-1.5$ & $11 / 5 \pm 2.7$ & $-5.7 \_2.8$ & 0.36 \\
\hline $\begin{array}{l}\text { ACR } \\
(\mu \mathrm{g} / \mathrm{mg})\end{array}$ & $17.1 \pm-3.7$ & $21.4 \pm 2.8$ & $-2 \_14.9$ & 0.13 \\
\hline GFR (mL/min) & $3.15 \pm-0.02$ & $6.44 \pm 0.88$ & $-1.35 \_3.34$ & 0.94 \\
\hline $\begin{array}{l}\mathrm{Zn} \\
(\mu \mathrm{g} / \mathrm{dL})\end{array}$ & $18.5 \pm 1.6$ & $14.1 \pm 1.5$ & $\begin{array}{l}-2.7 \_2.7 \\
\end{array}$ & 0.86 \\
\hline IIEF-5 Score & 0 & $0.16 \pm 0.3$ & $-0.03 \_0.08$ & 0.32 \\
\hline $\begin{array}{l}\text { Testosterone } \\
(\mathrm{nm} / \mathrm{dL})\end{array}$ & $1.5 \pm-0.2$ & $1.6 \pm-0.4$ & $-0.5 \_0.9$ & 0.57 \\
\hline
\end{tabular}

*-p value is $<0.05$ and statistically significant. We did not find any significant difference in none of variables within 2 groups' comparison. 
Table 3: mean of variation in clinical and biomedical parameters of total diabetes subjects in after zinc supplementation based on time of measurement

\begin{tabular}{|c|c|c|c|c|c|}
\hline \multirow[t]{2}{*}{ Variable } & \multicolumn{2}{|c|}{ Time of Measurement } & \multirow{2}{*}{$\begin{array}{c}\text { Mean of } \\
\text { variation }\end{array}$} & \multirow[t]{2}{*}{ CI95\% } & \multirow[t]{2}{*}{ P value } \\
\hline & $\begin{array}{c}\text { Before zinc } \\
\text { supplementation }\end{array}$ & $\begin{array}{c}\text { After zinc } \\
\text { supplementation }\end{array}$ & & & \\
\hline $\begin{array}{l}\text { SBP } \\
(\mathrm{mmHg})\end{array}$ & $136.7 \pm 15$ & $135.1 \pm 11.2$ & -1.6 & $-4.4 \_1.1$ & 0.24 \\
\hline $\begin{array}{l}\text { DBP } \\
(\mathrm{mmHg})\end{array}$ & $84.8 \pm 7.5$ & $83.7 \pm 5.9$ & -0.9 & $-3.2 \_1.2$ & 0.36 \\
\hline $\begin{array}{l}\text { FBS } \\
\text { (mg/dL) }\end{array}$ & $136.8 \pm 35.9$ & $115.6 \pm 20.2$ & -21.2 & $-31.5+-10.9$ & $0.0001>^{*}$ \\
\hline $\begin{array}{l}\text { HbA1C } \\
(\%)\end{array}$ & $8 \pm 0.8$ & $7.7 \pm 0.6$ & -0.3 & $-0.4{ }_{-}-0.2$ & $0.0001>^{*}$ \\
\hline $\begin{array}{l}\text { Cholesterol } \\
\text { (mg/dL) }\end{array}$ & $173.5 \pm 31.4$ & $169.4 \pm 30.8$ & $*-4.1$ & $-7.9-0.4$ & $0.031 *$ \\
\hline $\begin{array}{l}\text { TG } \\
(\mathrm{mg} / \mathrm{dL})\end{array}$ & $178.7 \pm 66.4$ & $176.9 \pm 64.4$ & -1.8 & $-10.4 \_6.9$ & 0.68 \\
\hline $\begin{array}{l}\mathrm{HDL} \\
(\mathrm{mg} / \mathrm{dL})\end{array}$ & $38.4 \pm 3.8$ & $39.5 \pm 2.3$ & 1.1 & $0.4 \_1.8$ & $0.002^{*}$ \\
\hline $\begin{array}{l}\text { LDL } \\
(\mathrm{mg} / \mathrm{dL})\end{array}$ & $100.6 \pm 27.9$ & $95.5 \pm 28$ & -5.1 & $-8.9+-1.3$ & $0.01 *$ \\
\hline $\begin{array}{l}\text { ACR } \\
(\mu g / m g)\end{array}$ & $177.5 \pm 241.4$ & $173.2 \pm 236$ & -3.7 & $-9 \_1.6$ & 0.22 \\
\hline GFR (mL/min) & $42.13 \pm 11.56$ & $42.11 \pm 11.71$ & -0.02 & $-1.21 \_1.16$ & 0.96 \\
\hline $\begin{array}{l}\mathrm{Zn} \\
(\mu \mathrm{g} / \mathrm{dL})\end{array}$ & $100.7 \pm 18.9$ & $102.3 \pm 19.6$ & 1.6 & $-4.1 \_7.4$ & 0.57 \\
\hline IIEF-5 Score & $13.9 \pm 5.92$ & $13.9 \pm 92.5$ & 0 & --- & $-\overline{--}$ \\
\hline $\begin{array}{l}\text { Testosterone } \\
\text { (nm/dL) }\end{array}$ & $8.9 \pm 1.9$ & $8.7 \pm 1.9$ & -0.2 & $-0.7 \_0.3$ & 0.39 \\
\hline
\end{tabular}


*-p value is $<0.05$ and statistically significant.

\section{Figures}



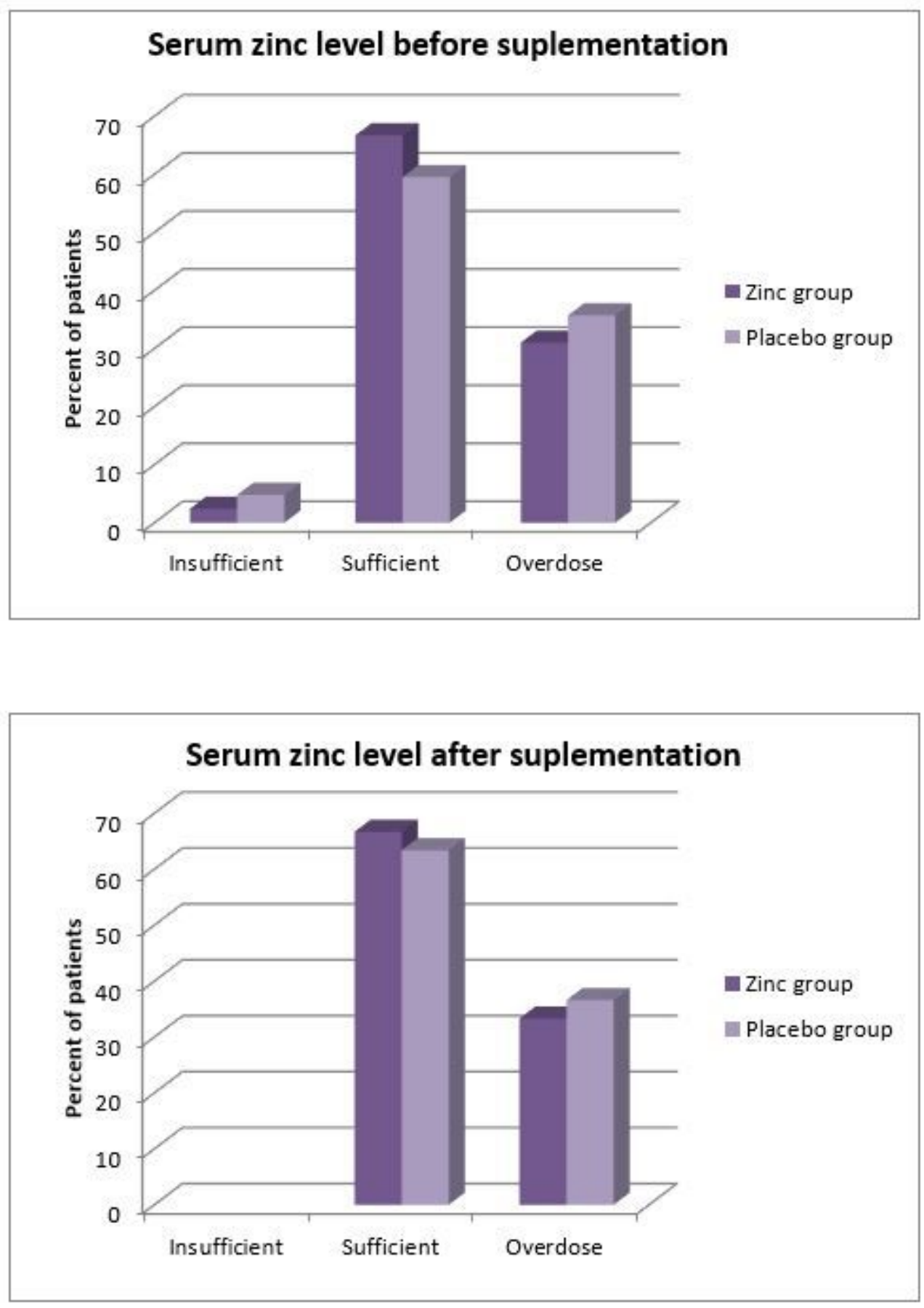

Figure 1

Serum zinc level before and after zinc supplementation in both experimental and placebo group 